\title{
THE EFFECT OF KNOWLEDGE MANAGEMENT, ORGANIZATIONAL CULTURE AND ORGANIZATIONAL LEARNING ON INNOVATION IN AUTOMOTIVE INDUSTRY
}

\author{
Kambiz ABDI ${ }^{1}$, Abbas MARDANI ${ }^{1}$, Aslan Amat SENIN ${ }^{1}$, Laura TUPENAITE ${ }^{2 *}$, \\ Jurga NAIMAVICIENE ${ }^{2}$, Loreta KANAPECKIENE ${ }^{2}$, Vladislavas KUTUT ${ }^{2}$ \\ ${ }^{1}$ Faculty of Management, Universiti Teknologi Malaysia, 81310 Johor Bahru, Johor \\ ${ }^{2}$ Department of Construction Management and Real Estate, \\ Vilnius Gediminas Technical University, Sauletekio al. 11, LT-10223 Vilnius, Lithuania
}

Received 03 December 2017; accepted 12 February 2018

\begin{abstract}
The main objective of this study was to examine the direct and indirect effects of organizational culture, knowledge management and organizational learning on innovation. The study combined knowledge-based view theory (KBV), competitive value framework to develop a new original theoretical framework for investigation of factors that affect innovation. Data was gathered from a survey of 279 companies supplying automobile parts to Iran Khodro Company, an Iranian leading automobile manufacturer. Study discovered that organizational culture and knowledge management influenced organizational innovation. Besides that, organizational learning played a significant role as a mediator in that relationship. However, knowledge management was not considered as a mediator in the relationship between organizational culture and organizational innovation. As a practical contribution, the findings of the study serve as a guideline for policy makers and managers in the formulation of policies and strategies for sustainable innovation. Knowing the effectiveness of the innovation can help the government to make decisions about the continuation of this policy. Moreover, study contributes to firm management in formulation of policies and strategies for sustainability in innovation context. Innovation assists organizations supplying the product or service in the automotive sector to operate innovatively, competitively and profitably.
\end{abstract}

Keywords: organizational culture, knowledge management, organizational learning, organizational innovation, knowledge-based view theory, automotive industry.

JEL classification: M14, D2, L2, O3, D83.

\section{Introduction}

In a turbulent economic environment, innovation is considered as a strategic driver to gain competitive advantage, also it increases the sustainability, productivity, economic growth and business competitiveness (Smit, Trigeorgis 2012). Innovation becomes an ongoing process

${ }^{\star}$ Corresponding author. E-mail: laura.tupenaite@vgtu.lt

This is an Open Access article distributed under the terms of the Creative Commons Attribution License (http://creativecommons. org/licenses/by/4.0/), which permits unrestricted use, distribution, and reproduction in any medium, provided the original author and source are credited. 
of learning, searching and exploring that result in new products, new techniques, new forms of organizations and eventually new markets (Eveleens 2010). However, the increasing dynamism and turbulence of the environment requires a new look at innovation (Davila et al. 2012). Therefore, it is necessary for firms to have capabilities enabling the innovation to be effective. Recently importance of knowledge management (KM) is emphasized. KM is defined as organization, creation, sharing and flow of knowledge within organizations (Lin 2014). Many researchers and practitioners have concluded that KM must facilitate creating new knowledge in order to gain and sustain competitive advantage, thus gaining knowledge successfully in management processes affect organizational innovation (OI) (Kaklauskas, Kanapeckiene 2005). Moreover, Shenbagavalli (2013) notes that KM is an important factor which contributes to gaining of sustained innovation that leads to sustainable competitive advantage. Therefore, knowledge maps (i.e. Ghosh et al. 2012; Hoła et al. 2015); fuzzy cognitive maps (i.e. Ferreira et al. 2017); KM systems and knowledge-based decision support systems (i.e. Tserng et al. 2016; Zavadskas et al. 2010; Kaklauskas et al. 2012, 2013a, 2013b; Ginevičius et al. 2011; Kanapeckiene et al. 2010) are developed for various industrial problems' solutions.

The researchers posited that organizational culture (OC) is intimately related to KM and its successful implementation is dependent upon the culture and they believed that $\mathrm{OC}$ is an essential factor in leading KM to innovation in organizations (Taleghani, Talebian 2013). In the true sense, the previous studies suggest that OC effects innovations by its effect on the $\mathrm{KM}$ process. Consequently, there is limited research on the relationship between OC and KM on OI in the industry (Tohidi, Jabbari 2012). Therefore, this study is focusing to close this gap by analysing the case of the Iran Khodro Company.

Organizational learning (OL) has emerged as one of the other capabilities of facing the changes coming from turbulent and dynamic environment (Vieira 2013). The first issue in this study appears referring to theory as it is believed that relation between KM and innovation must be studied along with other factors that contribute to innovation (Andreeva 2009). However, the mechanisms used by past studies still remain unclear and the relationship between KM and OL is not clearly discussed (Liao, Wu 2010). Therefore this study focuses on the new mechanism of testing the relationship among KM, OL, OI and analysis how this relationship can produce better understanding about enterprise innovation process.

The second issue addresses the necessity of considering an indirect relation between culture and innovation. The gap regarding the relation between OC and OI becomes highlighted by referring the relation between OC and OL on one side, and OL and OI on the other side. There are few studies focusing on the relation between OC and learning (Azadi et al. 2013). On the other hand, there is some evidence that OL is associated to innovation (Scarbrough 2003). Thus a mediating factor can be considered to facilitate the relation between of OC on innovation. However, Sanz-Valle et al. (2011) disclosed that culture, learning, and innovation have scarcely been examined together in the literature. According to Cameron and Quinn (2011), there are limited studies that have comprehensively and simultaneously examined different processes of KM on relationship between OC and OI. Besides, it is not clear what aspects of OC facilitate or inhibit the KM initiatives or have the greatest impact on organizational success or failure. 
This study was performed in Iran because the current situation of the Iran Khodro firms shows that firms need to innovate in order to maintain or increase their competitiveness. In addition due the lack of innovation, the learning mechanism seems to be absent in Iran Khodro (IKCO 2012). Furthermore, it has also been observed that the lack of quality and learning group level on one side, and lack of innovation and $\mathrm{KM}$ on the other side have been noticed as a problem during these past years in Iran Khodro Company (Tohidi, Jabbari 2012). In summary, there is still no consensus in the literature on the factors affecting firms' innovation, and how they relate with each other. Studies on antecedents of innovation remain fragmented and inconclusive.

Although research has been carried out to find out the relation among KM, OL, and OI, the variables have not been studied simultaneously (Moustaghfir, Schiuma 2013). Regarding the issue of innovation, there should be studies investigating issues on $\mathrm{KM}$, OL and OI along with each other (Liao, Wu 2010). Few studies concurrently examine the effect of OC on OI directly and through KM. Therefore, the result of the study in line with knowledge-based view (KBV) theory by integrating of the variables in the domain of KM and OI provides a new light to the current body of knowledge about the role of effective utilization of KM on OI. Therefore, the study opened new perspectives into KBV theory as well as internal resources and indicated how the innovative utilization of firm's internal resources in terms of organizational strategy leads to resources management in both the internal and external environments of organizations.

\section{Development of hypotheses}

The literature has acknowledged the importance of organization culture and knowledge management on organizational innovation. Moreover, the literature verified the vital role of knowledge management on organizational innovation. Furthermore, the literature provides clear evidence about role of organizational learning capability and organizational innovation. However, the literature has very limited evidences to highlight theoretically and comprehensively the effect of organizational culture on organizational innovation thorough knowledge management and organizational learning.

Keeping in mind the strong interrelationships between knowledge and innovation, it may be anticipated that the process of innovation can be formed as an end result of the organization's knowledge processes (Andreeva, Kianto 2011). Knowledge creation can be used to identify the process of development of new knowledge, and innovation to refer to the results of the successful application of this new knowledge (Brachos et al. 2007). Moreover, better understanding of the effect of KM on different types of innovation needs further study. Therefore, the following hypothesis is developed to investigate comprehensively the impact of $\mathrm{KM}$ on OI:

$\mathrm{H} 1$ : There is a positive relationship between $\mathrm{KM}$ and OI.

Generally, literature reckons that OC is needed for innovation which improves innovative behaviors and creativity of the individuals (Lee 2012). Kotter (2008) identified that the optimal culture for organizations pursuing long-term innovation and performance in a dynamic environment is an adaptive, learning culture - a culture that fosters and nurtures innovation. 
In literature, $\mathrm{OC}$ is deemed as one of the elements that is able to largely inspire innovative behavior amongst organizational members (Valencia et al. 2010). Culture's external orientation helped in improving innovation as it gives latest ideas from the market (Božić 2006). In short, according to literature that is mentioned above, it can be hypothesized that:

$\mathrm{H} 2$ : There is a positive relationship between OC and OI.

According to leading KM researchers (Davenport, Pruzak 2000) there is an indivisible relationship between OC and KM. Eckl (2012) noted that organizations with successful KM programs frequently cited their inherent culture as the crucial factor behind their achievement. Auernhammer and Hall (2014) stated that a culture that encourages knowledge sharing and openness is more conducive to the implementation of KM. Moreover, there is a certain OC with positive values and norms which have a positive effect on different types of KM (Pasher, Ronen 2011). Based on these statements, we conclude that OC affects KM. Thus, the following hypothesis formulated to open a new window about the effect of OC on KM:

H3: There is a positive relationship between OC and KM.

Schein (1996) suggested that OL failures can be affected by absence of communication between the different cultures in organization. Czerniewicz and Brown (2009) found that OC has a positive effect on OL culture and the learning culture systematically improves OL. Azadi et al. (2013) suggested that OC is positively related to OL. Despite that, the effect of OC on OL has been considered by researchers, but there are quite a few studies that have been conducted to investigate the effect of different types of OC. Therefore, the following hypothesis is presented for relationship between OC and OL:

$\mathrm{H} 4$ : There is a positive relationship between OC and OL.

$\mathrm{KM}$ can be a transformation tool or organizational change, as it is able to facilitate management in crafting a learning OC (Jennex 2007). Easterby-Smith and Lyles (2003) deem KM to concentrate upon the content, and OL to concentrate upon the process of the knowledge that a firm obtains, produces, handles and eventually utilizes. OL is perceived as a vibrant process on the basis of knowledge, which entails moving amongst the diverse action levels, starting from the personal to the group level and after that to the organizational level and back again. The following hypothesis is for highlighting the effect of KM on OL:

H5: There is a positive relationship between KM and OL.

The learning capabilities of a firm have a critical task in bringing innovations (Lin 2008). Various researches concentrate on one form of innovation, principally process or product innovation, or on one stage of the process of OL. For instance, Sanz-Valle et al. (2011) indicated that there is a positive relationship between OI and technical innovation. Few of previous studies have addressed core components of OL on OI. Thus, the following hypothesis was developed to consider the effects:

H6: There is a positive relationship between OL and OI.

Azadi et al. (2013) suggested that OC is positively related to OL. Moynihan and Landuyt (2009) suggested that OC could serve as a standard of cognitions or interpretations and therefore would affect the effectiveness of OL. A culture encouraging change is a critical feature to support OL. Especially in competitive environments an organization needs stronger adaptive culture to encourage cooperation and learning by its members (Liao et al. 2012). According to Liao and Wu (2010), higher levels of innovativeness in the firm's culture are 
associated with greater capacity for innovation to develop competitive advantage. Accordingly, we conclude that OC affect OI through OL, and thus propose the following hypothesis:

H7: The relationship between OC and OI is mediated by OL.

Mueller (2012) argued that the success of KM and the effectiveness of knowledge sharing in organizations are mainly associated with OC. Most programs of KM comprise a strong element of knowledge culture by means of which an OC of knowledge creation and sharing is laid emphasis on (Du Plessis 2007).

However, regardless of the objectives of KM in crafting, sustaining and improving innovation, there is a deficiency of experimental researches that inspected the correlation between innovation and KM (Al-Hakim, Hassan 2013). Thus, KM is positively associated with OL, OI, organizational growth, and competitive advantage. Chang and Lee (2007) conclude that OC had significantly positive effect on KM as well as on OI. Furthermore, KM is also significantly positively associated with OI. Accordingly, we conclude that OC affect OI through KM and propose the following hypothesis:

$\mathrm{H} 8$ : The relationship between OC and OI is mediated by KM.

$\mathrm{KM}$ is closely related to OL initiatives (Darroch 2005). This is because an OL process involves high degree of parallelism and depends on the knowledge base of organization. From literature review, KM affects OL positively. Like a system, an imperative input is $\mathrm{KM}$, a key process is OL, and then a significant output is OI (Liao, Wu 2010). As a final point, it is stated that systems of KM have a unique involvement concerning the development of continuous competitive advantage by means of innovation. Therefore, this study hypothesizes that KM affects OI through OL:

H9: The relationship between KM and OI is mediated by OL.

As discussed and mentioned in several hypotheses, the KBV of organizations are employed as the key theoretical framework in order to forecast and to infer the association

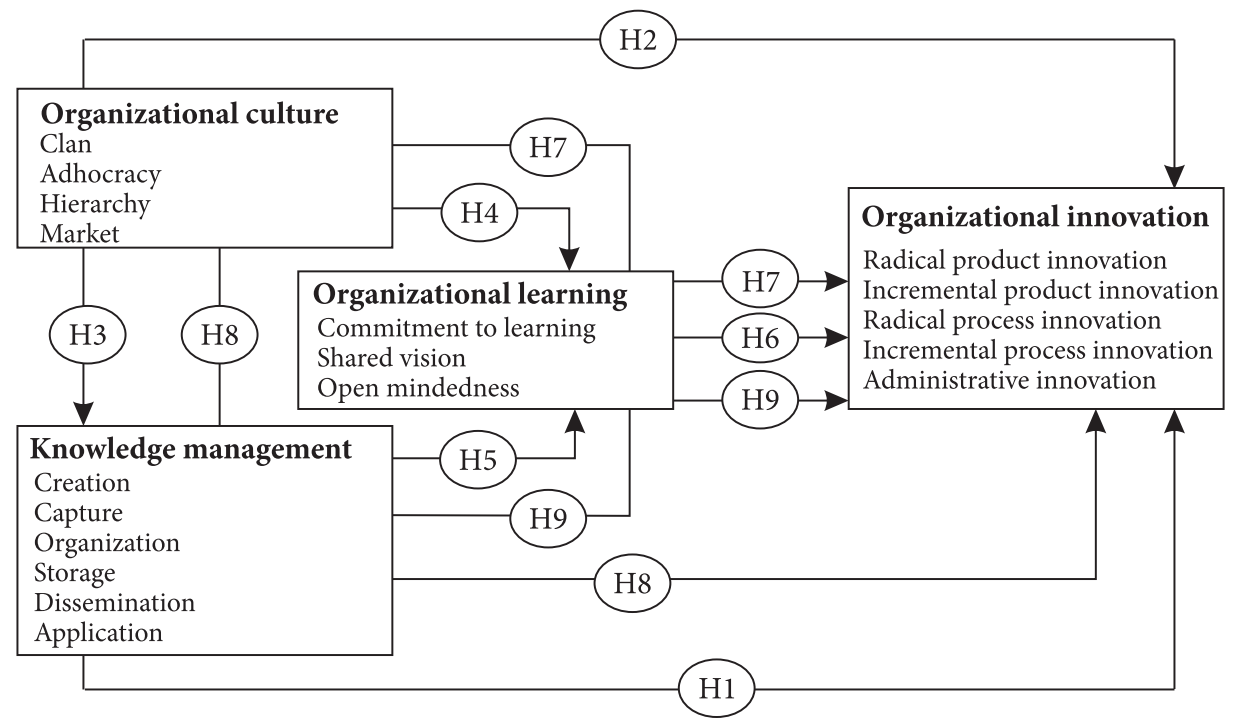

Figure 1. Theoretical framework of the study 
between variables. KBV approach of an organization regarded firms as entities that produce, incorporate and disseminate knowledge in order to form greater values. In accordance with this theory, if KM is applied efficiently as an intangible asset in different organizational levels then it leads to various matchless capacities and capabilities which bring greater performance via innovation. Figure 1 illustrates the theoretical framework of the study and hypotheses of this research.

\section{Research method}

In accordance to subject of the study, a survey method has been chosen for this research. The questionnaire has been developed based on literature review and previous empirical evidences that included OC, KM, OL and OI. Thus, a survey by questionnaire was conducted to provide sufficient evidence for the basic relationship of a variable and potential mediating factors.

This study follows probability sampling (PLS) by focusing on stratified random because the targeted population in the study is categorized demographically and the responses of all the groups are required on an equal basis. For the current research, we have used the structured equation modelling (SEM) by SmartPLS software. Therefore, using PLS is best preference for the research as it allows predicting the path relations and also helps to build the theories and validate them with confirmatory factor analysis without prerequisite of sample size and multivariate distribution of data. Finally, PLS-SEM as a second generation multivariate technique is capable of carrying out a simultaneous assessment of the model of measurement (the relationships shared between constructs and their corresponding indicators), and the structural model along with the objective of reducing the error variance (Ringle et al. 2005). The full-scale data was collected from September 2014 to March 2015. All constructs are measured with multiple items on a seven-point numerical rating scale.

Companies that supply automobile parts to Iran Khodro Company, an Iranian leading automobile manufacturer, were chosen for this case. Iran Khodro Company is the largest car maker in Iran and the Middle East that was founded in 1962. Regarding units produced, Iran's automobile industry is positioned as one of the top five in the developing countries. Iran Khodro had around 1.3 million units' annual automobile production (in 2008). The data for this study is obtained from auto parts manufacturers from the three branches, namely metallic, electric and polymeric over Iran with 650,000 direct and indirect employers (IKCO 2012). The instruments were distributed to the managers as the respondents of the current study in auto-parts manufacturing sector of Iran. The auto-parts manufacturing sector is one of the main suppliers of Iran Khodro Company because they have a significant impact on the process of Iran Khodro product. Iran Khodro has also integrated vertically in to the higher part of car manufacturing industry value chain. It has established the component manufacturing capability.

In total, there were 850 companies in Iran. For selection of sample size we used the methodology proposed by Krejcie and Morgan (1970). According to this methodology, for 850 respondents, we need 265 samples; therefore, for selection of these 265 samples, we distributed the questionnaires among all companies. In total, 320 questionnaires were received 
to obtain the desired number of usable questionnaires. From these 320 questionnaires, 272 questionnaires were usable and in the final round of data collection we additionally received seven usable questionnaires, therefore the final number of questionnaires for further analysis was 279 questionnaires.

The detailed results of the number of questionnaires distributed and the number of usable questionnaires are indicated in Table 1.

Table 1. Rate of response in main survey $\mathrm{N}=279$

\begin{tabular}{|l|c|}
\hline \multicolumn{1}{|c|}{ Description } & N \\
\hline Questionnaires received & 293 \\
\hline Returned but not usable questionnaires & 14 \\
\hline Usable questionnaires & 279 \\
\hline Total questionnaires distributed & 320 \\
\hline
\end{tabular}

As it is evident from the table, out of total number of $\mathrm{N}=279$, Metallic sector comprised the highest number of respondents with $42.3 \%$ of total response followed by Electric and Polymer sector with $29.7 \%$ and $28.0 \%$ respectively. In terms of firm size, the highest frequency belongs to small firms with $\mathrm{N}=106$. This number is followed by medium size firms with $\mathrm{N}=90$ and large firms $\mathrm{N}=83$. The last part in profile of respondents belongs to the location of main manufacturing sites of respondents (however, the main office is normally in capital or main cities). There were eight cities. The highest frequency belongs to the city of Karaj ( $44.1 \%$ of response), and the lowest to the city of Kerman which comprise a percentage of $2.2 \%$ of total response. A detailed presentation of percentage pertaining to each demographical characteristic is illustrated in the Table 2.

Table 2. Profile of respondents/units of analysis

\begin{tabular}{|l|l|c|c|}
\hline \multicolumn{2}{|l|}{} & Frequency & Percent \\
\hline \multirow{4}{*}{ Sub Sector } & Electric & 83 & $29.7 \%$ \\
\cline { 2 - 4 } & Metallic & 118 & $42.3 \%$ \\
\cline { 2 - 4 } & Polymer & 78 & $28.0 \%$ \\
\cline { 2 - 4 } & Total & 279 & $100.0 \%$ \\
\hline \multirow{5}{*}{ Firm Size } & Small: 10 to 50 & 106 & $38.0 \%$ \\
\cline { 2 - 4 } & Medium: 50 to 100 & 90 & $32.3 \%$ \\
\cline { 2 - 4 } & Large: 100 \& above & 83 & $29.7 \%$ \\
\cline { 2 - 4 } & Total & 279 & $100.0 \%$ \\
\hline \multirow{5}{*}{ different Cities } & City Karaj & 123 & $44.1 \%$ \\
\cline { 2 - 4 } & City Tabriz & 22 & $7.9 \%$ \\
\cline { 2 - 4 } & City Kerman & 6 & $2.2 \%$ \\
\cline { 2 - 4 } & City Kermanshah & 30 & $10.8 \%$ \\
\cline { 2 - 4 } & City Semnan & 20 & $7.2 \%$ \\
\cline { 2 - 4 } & City Mashhad & 30 & $10.8 \%$ \\
\cline { 2 - 4 } & City Shiraz & 26 & $9.3 \%$ \\
\cline { 2 - 4 } & City Babol & 279 & $100.0 \%$ \\
\cline { 2 - 4 } & Total & & \\
\hline
\end{tabular}




\subsection{Study variables}

According to objectives of this study, we provided the details of all variables in Table 3. According to Cameron and Quinn (2006), the Organizational Culture Assessment Instrument (OCAI) uses six factors to identify the four types of OC (Table 3). The instrument contains four questions for each category for a total of 24 questions. Therefore, each type of OC is assessed via a six-item scale. The dominant characteristics of the organization, or what the overall organization is like; the leadership style and approach that permeate the organization; the management of employees or the style that characterizes how employees are treated and what the working environment is like; the organizational glue or bonding that holds the organization together; the strategic emphases that define what areas of emphasis drive the organization's strategy; and the criteria of success that determine what gets rewarded and celebrated.

Table 3. Details of all variables

\begin{tabular}{|c|c|c|c|}
\hline Type of variable & Name of variable & Items & Reference \\
\hline \multirow{6}{*}{$\begin{array}{l}\text { Independents vari- } \\
\text { ables }\end{array}$} & \multirow{6}{*}{$\begin{array}{l}\text { Organizational } \\
\text { Culture }\end{array}$} & Criteria of Success (CS) & \multirow{6}{*}{$\begin{array}{l}\text { Cameron and } \\
\text { Quinn (2006) }\end{array}$} \\
\hline & & Dominant Characteristic (DC) & \\
\hline & & Management of Employees (ME) & \\
\hline & & Organizational Glue (OG) & \\
\hline & & Organizational Leadership (OL) & \\
\hline & & Strategic Emphases (SE) & \\
\hline \multirow{8}{*}{ Mediator variables } & \multirow{5}{*}{$\begin{array}{l}\text { Knowledge Man- } \\
\text { agement }\end{array}$} & Capture Knowledge (CA) & \multirow{5}{*}{ Lawson (2002) } \\
\hline & & Creation Knowledge (CK) & \\
\hline & & Dissemination Knowledge (DK) & \\
\hline & & Organization Knowledge (OK) & \\
\hline & & Storage Knowledge (SK) & \\
\hline & \multirow{3}{*}{$\begin{array}{l}\text { Organizational } \\
\text { Learning }\end{array}$} & Commitment to Learning (CTL) & \multirow{3}{*}{$\begin{array}{l}\text { Wang and Rafiq } \\
(2009)\end{array}$} \\
\hline & & Open-Mindedness (OM) & \\
\hline & & Shared Vision (SHV) & \\
\hline \multirow{5}{*}{$\begin{array}{l}\text { Dependent vari- } \\
\text { ables }\end{array}$} & \multirow{5}{*}{$\begin{array}{l}\text { Organizational } \\
\text { Innovation }\end{array}$} & Administrative Innovation (AI) & \multirow{5}{*}{$\begin{array}{l}\text { Jansen et al. (2006) } \\
\text { Cheng and Shiu } \\
\text { (2008) }\end{array}$} \\
\hline & & $\begin{array}{l}\text { Incremental Product Innovation } \\
\text { (IPDI) }\end{array}$ & \\
\hline & & $\begin{array}{l}\text { Incremental Process Innovation } \\
\text { (IPRC) }\end{array}$ & \\
\hline & & Radical product Innovation (RPDI) & \\
\hline & & Radical process Innovation (RPRI) & \\
\hline
\end{tabular}

\section{Measurement model}

Based on the evaluation of measurement model, three reflective indicators had outer loading less than 0.7 (Table 4). These indicators/items/measures belonged to OL.OM, OL.CTL, and 
OL.SHV. The items with low loadings have been removed from further analysis. However, according to Hair et al. (2010), a loading above 0.5 should not be removed if its removal changes the composite reliability. Therefore, items with low loadings were removed if their removal improved the AVE (Figure 2).

Table 4. The result of measurement model - Convergent validity assessment

\begin{tabular}{|c|c|c|c|c|c|}
\hline $\begin{array}{c}\text { Second-order } \\
\text { constructs }\end{array}$ & $\begin{array}{l}\text { First-order } \\
\text { constructs }\end{array}$ & $\mathrm{AVE}^{\mathrm{c}}$ & $\mathrm{CR}^{\mathrm{c}}$ & Loadings & $\begin{array}{c}\text { No of items } \\
\text { deleted }\end{array}$ \\
\hline \multirow{6}{*}{ KM } & $\mathrm{AK}$ & \multirow{6}{*}{0.65} & \multirow{6}{*}{0.917} & 0.793 & \multirow{6}{*}{ 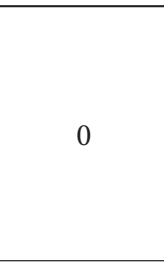 } \\
\hline & $\mathrm{CA}$ & & & 0.809 & \\
\hline & $\mathrm{CK}$ & & & 0.823 & \\
\hline & DK & & & 0.848 & \\
\hline & OK & & & 0.798 & \\
\hline & SK & & & 0.763 & \\
\hline \multirow{6}{*}{ OC } & $\mathrm{CS}$ & \multirow{6}{*}{0.54} & \multirow{6}{*}{0.874} & 0.788 & \multirow{6}{*}{0} \\
\hline & DC & & & 0.781 & \\
\hline & ME & & & 0.693 & \\
\hline & OG & & & 0.810 & \\
\hline & $\mathrm{OL}$ & & & 0.577 & \\
\hline & SE & & & 0.734 & \\
\hline \multirow{5}{*}{ OI } & $\mathrm{AI}$ & \multirow{5}{*}{0.641} & \multirow{5}{*}{0.899} & 0.779 & \multirow{5}{*}{0} \\
\hline & IPDI & & & 0.812 & \\
\hline & IPRC & & & 0.810 & \\
\hline & RPDI & & & 0.814 & \\
\hline & RPRI & & & 0.789 & \\
\hline \multirow{3}{*}{ OL } & CTL & \multirow{3}{*}{0.787} & \multirow{3}{*}{0.917} & 0.899 & \multirow{3}{*}{0} \\
\hline & OM & & & 0.819 & \\
\hline & SHV & & & 0.939 & \\
\hline
\end{tabular}

\subsection{Discriminant validity}

After confirming the convergent validity, the discriminant validity should be assessed. Hence, results of both tables clearly indicate that all second order constructs exhibit discriminant validity. Cross loading table provides the square of correlations in order to have more insight in establishing discriminant validity. Hence, the results presented in Table 5 demonstrate adequate discriminant and convergent validity among first order or LOC level.

Table 5. Latent variable correlation - Discriminant validity assessment using Fornell's and Larcker's (1981) criteria

\begin{tabular}{|c|c|c|c|c|}
\hline & KM & ORG.CULT & ORG.INNOV & ORG.LRN \\
\hline KM & 0.806 & & & \\
\hline ORG.CULT & 0.384 & 0.735 & & \\
\hline ORG.INNOV & 0.341 & 0.430 & 0.801 & \\
\hline ORG.LRN & 0.339 & 0.367 & 0.501 & 0.887 \\
\hline
\end{tabular}




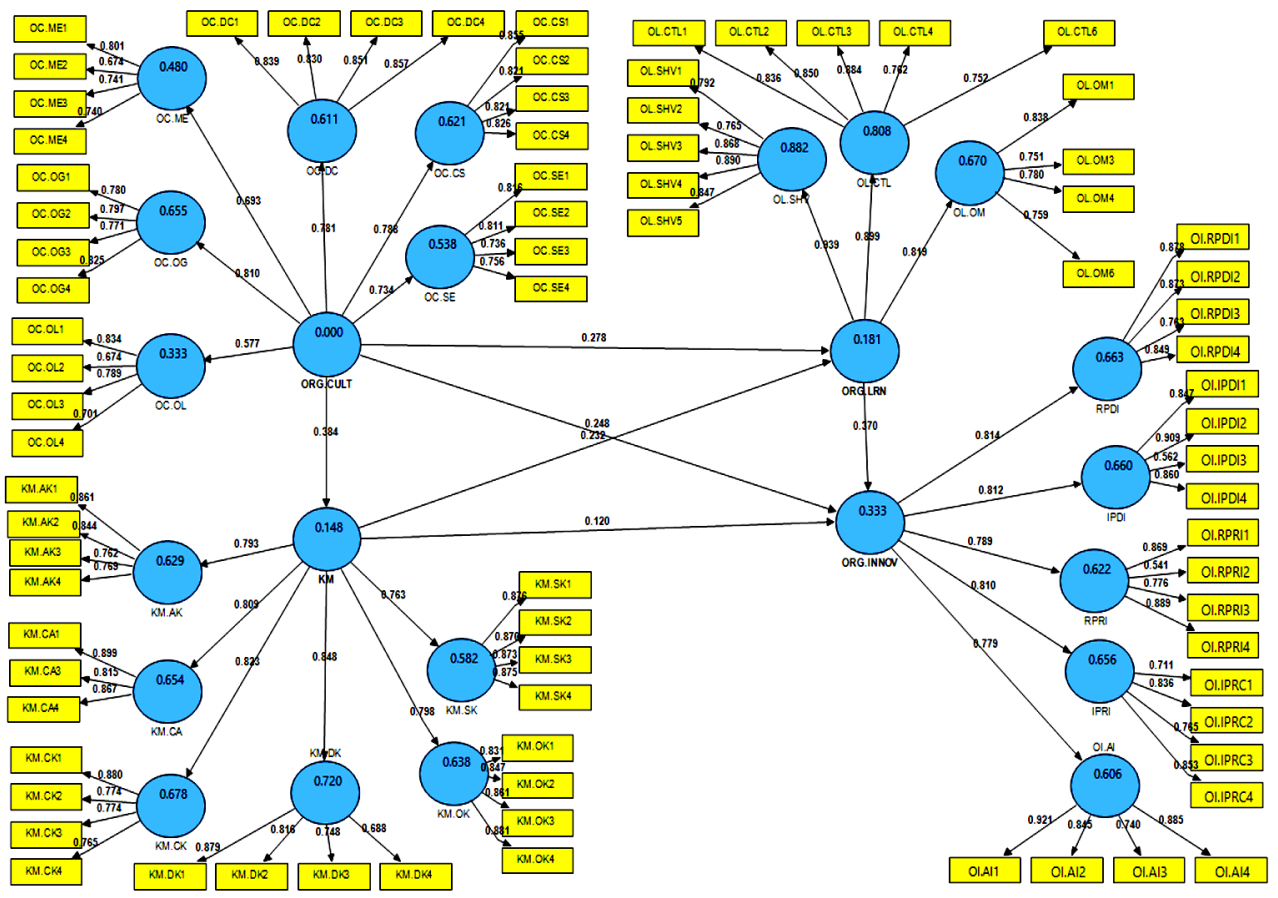

Figure 2. The measurement model with loadings and coefficients

\subsection{Structural model}

A PLS-SEM approach has been selected to carry out the model estimation and evaluation of results. Data has been applied to PLS-SEM software known as Smart PLS M3 version 2.0 (Ringle et al. 2005). This procedure yielded the generation of path coefficients and $\mathrm{R}^{2}$ squares. $\mathrm{R}^{2}$ squares were calculated to evaluate predictive power of the structural model (Barclay et al. 1995). OC, KM, and OL together explained $33.3 \%$ of the variance in OI.

A bootstrapping technique with a re-sampling of 3000 has been performed by Smart PLS software to calculate path estimates and t-statistics to test the significance of the hypothesized relationships. It should be noted the hypotheses of this study are 1-tailed hypotheses. Thus, given $t$-value for 1 tailed test has been used for assessing significant paths. Such cut-off values are: ${ }^{\star} \mathrm{p}<0.1(\mathrm{t}>1.28),{ }^{* *} \mathrm{p}<0.05(\mathrm{t}>1.645)$, and ${ }^{\star * *} \mathrm{p}<0.01(\mathrm{t}>2.33)$ (Hair et al. 2013). Therefore, all the hypotheses concerning a direct effect of an exogenous variable on an endogenous variable are supported (Table 6). However, the effect size of each exogenous variable on an endogenous variable has been calculated according to Cohen's effect size (Figure 3). The remaining hypotheses concerning indirect effects or so called mediating effects were tested in subsequent sections using the bootstrapping procedure. 
Table 6. Testing results of direct hypotheses

\begin{tabular}{|c|c|c|c|c|c|}
\hline Hypothesis & Relationship & Beta & Std. Error & T-Value & Decision \\
\hline $\mathrm{H} 1$ & $\mathrm{KM} \rightarrow \mathrm{OI}$ & $0.120^{\star *}$ & 0.058 & 2.054 & Supported \\
\hline $\mathrm{H} 2$ & $\mathrm{OC} \rightarrow \mathrm{OI}$ & $0.248^{\star * \star}$ & 0.063 & 3.920 & Supported \\
\hline H3 & $\mathrm{OC} \rightarrow \mathrm{KM}$ & $0.384^{\star \star * \star}$ & 0.059 & 6.495 & Supported \\
\hline $\mathrm{H} 4$ & $\mathrm{OC} \rightarrow \mathrm{OL}$ & $0.278^{\star * *}$ & 0.062 & 4.516 & Supported \\
\hline H5 & $\mathrm{KM} \rightarrow \mathrm{OL}$ & $0.232^{\star * \star}$ & 0.061 & 3.818 & Supported \\
\hline H6 & $\mathrm{OL} \rightarrow \mathrm{OI}$ & $0.370^{\star \star \star}$ & 0.055 & 6.718 & Supported \\
\hline & \multicolumn{2}{|c|}{ OI } & \multicolumn{2}{|c|}{$\mathrm{OL}$} & KM \\
\hline $\begin{array}{l}\mathrm{R}^{2} \text { for endog- } \\
\text { enous variables }\end{array}$ & \multicolumn{2}{|c|}{.333 or $33.3 \%$} & \multicolumn{2}{|c|}{0.181 or $18.1 \%$} & 0.148 or $14.8 \%$ \\
\hline
\end{tabular}

\subsection{Results of mediation analysis}

This process has been carried out by using IBM SPSS. Therefore, given the VAF measure, it has been supported that: OL mediates the relationship between OC on OI and KM on OI, while such effect for KM was not found, as it is shown in Tables 7-10. Therefore, KM has no mediator role.

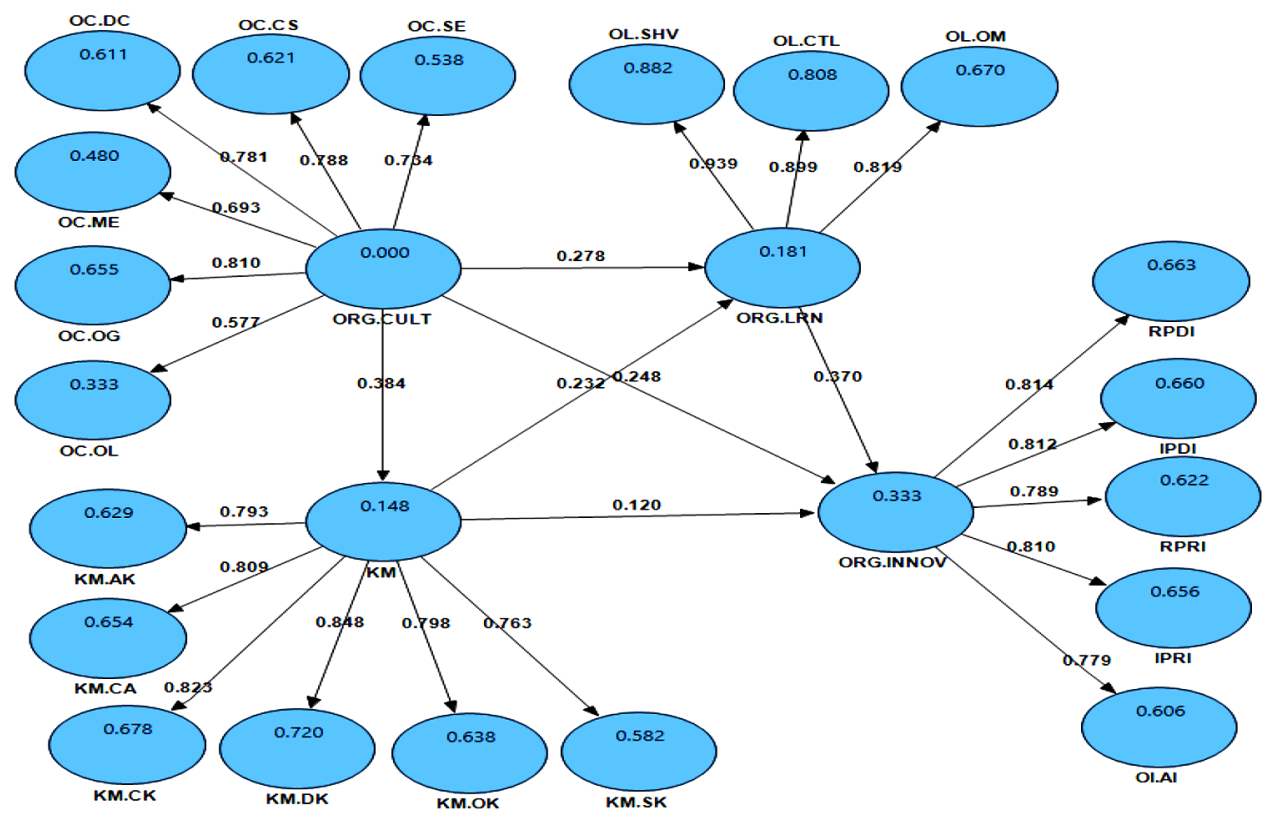

Figure 3. PLS algorithm results for the structural model 
Table 7. Direct and total effect

\begin{tabular}{|c|c|c|c|c|c|}
\hline Relationships & $\begin{array}{c}\text { Coefficient } \\
\text { (Unstandardized) }\end{array}$ & Standard error & $\mathrm{t}$ & $\mathrm{p}$ & $\begin{array}{l}\text { Significant } \\
\text { effect/path }\end{array}$ \\
\hline \multicolumn{6}{|c|}{ IV to Mediators } \\
\hline $\begin{array}{l}\text { organizational culture } \\
\rightarrow \text { knowledge } \\
\text { management }\end{array}$ & 0.451 & 0.065 & 6.89 & 0.000 & Exists \\
\hline $\begin{array}{l}\text { organizational culture } \\
\rightarrow \text { organizational } \\
\text { learning }\end{array}$ & 0.484 & 0.074 & 6.50 & 0.000 & Exists \\
\hline $\begin{array}{l}\text { knowledge manage- } \\
\text { ment } \rightarrow \text { organizational } \\
\text { learning }\end{array}$ & 0.380 & 0.063 & 5.950 & 0.000 & Exists \\
\hline \multicolumn{6}{|c|}{ Direct effects of mediators on DV } \\
\hline $\begin{array}{l}\text { knowledge manage- } \\
\text { ment } \rightarrow \text { organizational } \\
\text { innovation }\end{array}$ & 0.108 & .0494 & 2.20 & .0283 & Exists \\
\hline $\begin{array}{l}\text { organizational learning } \\
\rightarrow \text { organizational } \\
\text { innovation }\end{array}$ & .291 & .0433 & 6.73 & 0.000 & Exists \\
\hline $\begin{array}{l}\text { organizational learning } \\
\rightarrow \text { organizational } \\
\text { innovation (H9) }\end{array}$ & .348 & .0431 & 7.97 & 0.000 & Exists \\
\hline \multicolumn{6}{|c|}{ IV on DV (Total effect) } \\
\hline $\begin{array}{l}\text { organizational culture } \\
\rightarrow \text { organizational in- } \\
\text { novation }\end{array}$ & 0.451 & 0.057 & 7.84 & 0.000 & Exists \\
\hline $\begin{array}{l}\text { knowledge manage- } \\
\text { ment } \rightarrow \text { organizational } \\
\text { innovation }\end{array}$ & 0.304 & 0.050 & 5.998 & 0.000 & Exists \\
\hline \multicolumn{6}{|c|}{ IV on DV (Direct effect) } \\
\hline $\begin{array}{l}\text { organizational culture } \\
\rightarrow \text { organizational in- } \\
\text { novation }\end{array}$ & 0.26 & 0.058 & 4.43 & 0.000 & Exists \\
\hline $\begin{array}{l}\text { knowledge manage- } \\
\text { ment } \rightarrow \text { organizational } \\
\text { innovation }\end{array}$ & 0.173 & 0.048 & 3.568 & 0.004 & Exists \\
\hline
\end{tabular}

Table 8. Normal theory tests

\begin{tabular}{|l|c|c|c|c|c|}
\hline \multicolumn{1}{|c|}{ Indirect effect } & Effect & $\begin{array}{c}\text { Standard } \\
\text { error }\end{array}$ & $\mathrm{Z}$ & $\mathrm{p}$ & Mediation \\
\hline $\begin{array}{l}\text { organizational culture } \rightarrow \text { know- } \\
\text { ledge management } \rightarrow \text { organiza- } \\
\text { tional innovation }\end{array}$ & 0.0491 & 0.0233 & 2.11 & 0.034 & At $5 \%$ \\
\hline $\begin{array}{l}\text { organizational culture } \rightarrow \text { orga- } \\
\text { nizational learning } \rightarrow \text { organiza- } \\
\text { tional innovation }\end{array}$ & 0.1415 & 0.0301 & 4.69 & 0.000 & Exists \\
\hline
\end{tabular}


End of Table 8

\begin{tabular}{|l|c|c|c|c|c|}
\hline \multicolumn{1}{|c|}{ Indirect effect } & Effect & $\begin{array}{c}\text { Standard } \\
\text { error }\end{array}$ & $\mathrm{Z}$ & $\mathrm{p}$ & Mediation \\
\hline $\begin{array}{l}\text { Total: organizational culture } \rightarrow \\
\text { knowledge management }+ \text { orga- } \\
\text { nizational learning) } \rightarrow \text { organiza- } \\
\text { tional innovation }\end{array}$ & 0.1906 & 0.0362 & 5.2710 & 0.000 & Exists \\
\hline $\begin{array}{l}\text { knowledge management } \rightarrow \text { orga- } \\
\text { nizational learning } \rightarrow \text { organiza- } \\
\text { tional innovation }\end{array}$ & 0.1308 & 0.0274 & 4.7817 & 0.000 & Exists \\
\hline
\end{tabular}

Table 9. Bootstrapping results

\begin{tabular}{|l|c|c|c|c|c|c|c|}
\hline \multicolumn{1}{|c|}{$\begin{array}{c}\text { Indirect } \\
\text { effect }\end{array}$} & Beta (a*b) & $\begin{array}{c}\text { Standard } \\
\text { error }\end{array}$ & $\begin{array}{c}\text { Indirect to } \\
\text { direct }\end{array}$ & $\begin{array}{c}\text { Indirect to } \\
\text { total }\end{array}$ & $\begin{array}{c}\text { Boot 95\% confidence } \\
\text { intervals }\end{array}$ & $\begin{array}{c}\text { Effect } \\
\text { exists }\end{array}$ \\
\hline $\begin{array}{l}\text { organi- } \\
\text { zational } \\
\text { culture } \rightarrow \\
\text { knowledge } \\
\text { management } \\
\rightarrow \text { organiza- } \\
\text { tional inno- } \\
\text { vation }\end{array}$ & 0.050 & 0.026 & $19.2 \%$ & $16.2 \%$ & 0.003 & 0.108 & No \\
\hline $\begin{array}{l}\text { organiza- } \\
\text { tional cul- } \\
\text { ture } \rightarrow \text { or- } \\
\text { ganizational } \\
\text { learning } \rightarrow \\
\text { organiza- } \\
\text { tional inno- } \\
\text { vation }\end{array}$ & 0.141 & 0.033 & $54.2 \%$ & $45.5 \%$ & 0.083 & 0.214 & Yes \\
\hline $\begin{array}{l}\text { Total: orga- } \\
\text { nizational } \\
\text { culture } \rightarrow \\
\text { (knowledge } \\
\text { management } \\
+ \text { organi- } \\
\text { zational } \\
\text { learning) } \\
\text { organiza- } \\
\text { tional inno- } \\
\text { vation }\end{array}$ & 0.192 & 0.044 & $73.8 \%$ & $42.5 \%$ & 0.113 & 0.288 & Yes \\
\hline $\begin{array}{l}\text { knowledge } \\
\text { management } \\
\begin{array}{l}\rightarrow \text { organiza- } \\
\text { tional learn- } \\
\text { ing or- } \\
\text { ganizational } \\
\text { innovation }\end{array}\end{array}$ & 0.130 & 0.028 & $75.1 \%$ & $42.5 \%$ & 0.081 & 0.195 & Yes \\
\hline
\end{tabular}


Table 10. Summary of mediation hypotheses

\begin{tabular}{|c|l|l|l|}
\hline $\mathrm{N}$ & \multicolumn{1}{|c|}{ Abbreviation } & \multicolumn{1}{|c|}{ Decision } \\
\hline $\mathrm{H} 7$ & $\begin{array}{l}\text { organizational culture } \rightarrow \text { organizational learning } \rightarrow \text { organiza- } \\
\text { tional innovation }\end{array}$ & Supported \\
\hline $\mathrm{H} 8$ & $\begin{array}{l}\text { organizational culture } \rightarrow \text { knowledge management } \rightarrow \text { organiza- } \\
\text { tional innovation }\end{array}$ & Not supported \\
\hline $\mathrm{H} 9$ & $\begin{array}{l}\text { knowledge management } \rightarrow \text { organizational learning } \rightarrow \text { organi- } \\
\text { zational innovation }\end{array}$ & Supported \\
\hline
\end{tabular}

\section{Discussion}

This section synthesizes the empirical findings to answer research questions of the study. It has been found that OC has an indirect effect on OI through organization learning. OL is dependent on OC. In other words, learning in an organization is in fact part of the culture. Therefore, if an organization strives to improve its innovative capabilities, it needs to focus on bringing an appropriate cultural environment which supports continuous learning. This study has demonstrated this relationship and found significant impact of culture on learning. Therefore, an OC that focuses on improving OL practices eventually brings more innovation in an organization. Cultural patterns of an organization can be an indication of potential innovativeness in Iranian auto-part manufacturing. Hence, we conclude that organization learning in firms can be considered as a culture enhancing mechanism that directs all members of the organization towards a shared vision of innovativeness in all core processes and products. Thus, Iran Khodro could become a more learning organization by developing an OC that values commitment to learning, shared vision and open mindedness. It has been found that OC has no indirect effect on OI through KM. Therefore, KM has no mediator role in the causal relationship between culture and innovation. Similarly, OC affects the KM and OI relationship individually. Since OC varies across regions and countries the relationship interplay is quite subjective. From the results obtained testing the hypotheses, it can be seen that the inclusion of the KM variable in the model significantly and positively increased the variance explained in innovation. This indicates that KM variable provides unique information in explaining the variance in innovation. However, the result from our study shows that KM has a significant association with OI. On the other hand, the results show that the relationship between KM and OI can be improved significantly by adding OL in the relate model. This finding shows that the more KM is in organization, the greater the OL capability. Consequently, OL has a significant role in bringing knowledge repositories up-to-date through regular training and retraining (Azadi et al. 2013). Skillful KM can bring significant benefits including labour productivity growth, an increase in quality of provided services and also a strengthening of the competitive position of an enterprise (Hoła et al. 2015).

In recent years, some of works investigated the relationship between $\mathrm{KM}$, OC, organizational culture, OL and innovation (Ferraris et al. 2017; Donate, Sánchez de Pablo 2015; Fraj et al. 2015; Hogan, Coote 2014; Lopes et al. 2017; Obeidat et al. 2017).

Fraj et al. (2015) investigated the role of organizational innovation and organizational learning as determinants of environmental success. The findings confirm that a proactive 
environmental strategy and innovation favor organizational competitiveness. However, a learning orientation does not directly predict organizational competitiveness (Fraj et al. 2015).

Donate and Sánchez de Pablo (2015) examined the links between KM practices, organizational leadership and organizational innovation. The finding of this study show that KM practices had the mediate effects on leadership and innovation. Hogan and Coote (2014) explored the relationship between OC, innovation and organizational performance. The findings of this paper indicated that OC partially had the mediate impacts on innovation and organizational performance. Lopes et al. (2017) explored the relationships between KM, innovation and organizational sustainability. The findings of this paper demonstrated that development of innovation had the significant changes in OC and organizational sustainability. Ferraris et al. (2017) explored the links between KM, innovative performance and research and development $(\mathrm{R} \& \mathrm{D})$. The findings of this paper show that KM had the moderating effect on innovative performance and R\&D. Obeidat et al. (2017) examined the influence of intellectual capital on organizational innovation by mediating role of KM. The findings of this study demonstrated that KM had the moderating impact in relationship between organizational innovation and intellectual capital.

\section{Conclusions}

The main objective of this study was to examine the direct and indirect effects of organizational culture, knowledge management and organizational learning on innovation. This study combined KBV, competitive value framework to develop a new theoretical framework to investigate factors affecting innovation. The study provides new insights to better understand the mechanisms supporting this relation by analyzing the impact of KM on innovation in auto part manufacturing. Thus, one of the main conclusions of the study is that KM has been found as a significant mechanism to enhance innovation and corporate performance. Specifically, companies know that with a clear KM strategy they can be more innovative, achieve better financial results, improve their processes and develop capabilities of human resources. The benefits of innovation have been shown to be both comprehensive and sustainable in the long-term for the whole industry.

Review of literature indicates that despite the unique features of the innovation studies on the impact of KM on OI, there are few such studies on certified companies. The present study was done to enlighten the relationship among OC, KM and OI as mediated by OL. The results revealed that there is a significant and positive relationship between OC and OI. Moreover, the result confirmed a significant and positive relationship between KM and OI. Furthermore, the results disclosed that KM has no mediator role in the relationship between OC and OI.

The limitation of the study is related to using a sample of Iranian automotive industry for testing the hypotheses. Considering the sample population, the results of this study are cautiously generalizable to the automotive industry in other contexts. In other words, using a limited sample of Iranian automotive industries that operate in a developing country under specific circumstances limits the generalizability the results of the study to other contexts especially in the context of developed countries. Regarding the limitation of this study there 
are some recommendations for future research suggested in this section.

The findings of this study were obtained from a sample of Iranian automotive industries. Future researchers can repeat this study in other countries and with other sampling frames. The study examined the relationship between OC and KM on OI directly and through OL and $\mathrm{KM}$ in just one industry: the automotive industry. This study may be replicated across industries to determine intra-industry effect. Unfortunately, only a few studies have taken into account these intra-industry effects of firm's heterogeneity on performance variation in Iran. Further research could also be conducted to determine the firm effect, industry effect and industry segment or intra industry effect on different elements of innovation and organizational performance in the context of quality management system. To generate achievable policy strategies and development targets with regard to enhanced innovation through culture, learning, and $\mathrm{KM}$, there is a need for more case studies at the local level to allow further assessment of local dimensions of the subject.

\section{References}

Al-Hakim, L. A. Y.; Hassan, S. 2013. Knowledge management strategies, innovation, and organisational performance: An empirical study of the Iraqi MTS, Journal of Advances in Management Research 10(1): 58-71. https://doi.org/10.1108/09727981311327767

Andreeva, T. 2009. Tensions between knowledge creation and knowledge sharing: individual preferences of employees in knowledge-intensive organizations. Chapter 28, in D. Jemielniak, J. Kociatkiewicz (Eds.). Handbook of research on knowledge-intensive organizations. IGI Global. https://doi.org/10.4018/978-1-60566-176-6.ch028

Andreeva, T.; Kianto, A. 2011. Knowledge processes, knowledge-intensity and innovation: a moderated mediation analysis, Journal of Knowledge Management 15(6): 1016-1034. https://doi.org/10.1108/13673271111179343

Auernhammer, J.; Hall, H. 2014. Organizational culture in knowledge creation, creativity and innovation: Towards the Freiraum model, Journal of Information Science 40(2): 154-166.

Azadi, A.; Farsani, M. E.; Rizi, R. M.; Aroufzad, S. 2013. Relationship between organizational culture and organizational learning among employees in physical education organizations, European Journal of Sports and Exercise Science 2(1): 12-16.

Barclay, D.; Higgins, C.; Thompson, R. 1995. The partial least squares (PLS) approach to causal modeling: Personal computer adoption and use as an illustration, Technology Studies 2(2): 285-309.

Božić, L. 2006. The effects of market orientation on product innovation, Privredna kretanja i ekonomska politika [Economic Trends and Economic Policy] 107: 46-65.

Brachos, D.; Kostopoulos, K.; Soderquist, K. E.; Prastacos, G. 2007. Knowledge effectiveness, social context and innovation, Journal of Knowledge Management 11(5): 31-44. https://doi.org/10.1108/13673270710819780

Cameron, K. S.; Quinn, R. E. 2006. Diagnosing and changing organizational culture. Wiley.

Cameron, K. S.; Quinn, R. E. 2011. Diagnosing and changing organizational culture: Based on the competing values framework. New York: John Wiley \& Sons.

Chang, S.-C.; Lee, M.-S. 2007. A study on relationship among leadership, organizational culture, the operation of learning organization and employees' job satisfaction, The Learning Organization 14(2): 155-185. https://doi.org/10.1108/09696470710727014

Cheng, C. J.; Shiu, E. C. 2008. Re-innovation: The construct, measurement, and validation, Technovation 28(10): 658-666. https://doi.org/10.1016/j.technovation.2007.08.002 
Czerniewicz, L.; Brown, C. 2009. A study of the relationship between institutional policy, organisational culture and e-learning use in four South African universities, Computers \& Education 53(1): 121-131. https://doi.org/10.1016/j.compedu.2009.01.006

Darroch, J. 2005. Knowledge management, innovation and firm performance, Journal of Knowledge Management 9(3): 101-115. https://doi.org/10.1108/13673270510602809

Davenport, T. H.; Pruzak, L. 2000. Working knowledge: How organizations manage what they know. Harvard: Harvard Business Press.

Davila, T.; Epstein, M.; Shelton, R. 2012. Making innovation work: How to manage it, measure it, and profit from it. Upper Saddle River: FT Press.

Donate, M. J.; Sánchez de Pablo, J. D. 2015. The role of knowledge-oriented leadership in knowledge management practices and innovation, Journal of Business Research 68(2): 360-370. https://doi.org/10.1016/j.jbusres.2014.06.022

Du Plessis, M. 2007. The role of knowledge management in innovation, Journal of Knowledge Management 11(4): 20-29. https://doi.org/10.1108/13673270710762684

Easterby-Smith, M.; Lyles, M. 2003. Re-reading “Organizational learning”: Selective memory, forgetting, and adaptation, The Academy of Management Executive 17(2): 51-55.

Eckl, V. C. 2012. Barriers of knowledge transfer, in Proceedings of the 2012 DRUID Summer Conference, 2012, Copenhagen, Denmark.

Eveleens, C. 2010. Innovation management; a literature review of innovation process models and their implications [online], [cited 10 May 2017]. Available from Internet: https://s3.amazonaws.com/academia.edu.documents.

Ferraris, A.; Santoro, G.; Dezi, L. 2017. How MNC's subsidiaries may improve their innovative performance? The role of external sources and knowledge management capabilities, Journal of Knowledge Management 21(3): 540-552. https://doi.org/10.1108/JKM-09-2016-0411

Ferreira, F. A. F.; Ferreira, J. J. M.; Fernandes, C. I. M. A. S.; Meidute-Kavaliauskienė, I.; Jalali, M. S. 2017. Enhancing knowledge and strategic planning of bank customer loyalty using fuzzy cognitive maps, Technological and Economic Development of Economy 23(6): 860-876. http://dx.doi.org/10.3846/20294913.2016.1213200

Fornell, C.; Larcker, D. F. 1981. Evaluating structural equation models with unobservable variables and measurement error, Journal of Marketing Research 18(1): 39-50. https://doi.org/10.2307/3151312

Fraj, E.; Matute, J.; Melero, I. 2015. Environmental strategies and organizational competitiveness in the hotel industry: The role of learning and innovation as determinants of environmental success, Tourism Management 46: 30-42. https://doi.org/10.1016/j.tourman.2014.05.009

Ghosh, S.; Amaya, L.; Skibniewski, M. J. 2012. Identifying areas of knowledge governance for successful projects, Journal of Civil Engineering and Management 18(4): 495-504. https://doi.org/10.3846/13923730.2012.700642

Ginevičius, T.; Kaklauskas, A.; Kazokaitis, P. 2011. Knowledge model for integrated construction project management, Business: Theory and Practice 12(2): 162-174. https://doi.org/10.3846/btp.2011.17

Hair, J. F.; Black, W. C.; Babin, B. J.; Anderson, R. E. 2010. Multivariate data analysis. Upper Saddle River: Prentice-Hall.

Hair, J.; Hult, T.; Ringle, C.; Sarstedt, M. 2013. A primer on partial least squares structural equation modeling (PLS-SEM). New York: Sage Publications.

Hogan, S. J.; Coote, L. V. 2014. Organizational culture, innovation, and performance: A test of Schein's model, Journal of Business Research 67(8): 1609-1621. https://doi.org/10.1016/j.jbusres.2013.09.007

Hoła, B.; Sawicki, M.; Skibniewski, M. 2015. An IT model of a Knowledge Map which supports management in small and medium-sized companies using selected Polish construction enterprises as an example, Journal of Civil Engineering and Management 21(8): 1014-1026.

https://doi.org/10.3846/13923730.2015.1030865 
IKCO. 2012. Iran Khodro company.

Jansen, J. J.; Van Den Bosch, F. A.; Volberda, H. W. 2006. Exploratory innovation, exploitative innovation, and performance: Effects of organizational antecedents and environmental moderators, Management Science 52(11): 1661-1674. https://doi.org/10.1287/mnsc.1060.0576

Jennex, M. E. 2007. Knowledge management in modern organizations. IGI Global. https://doi.org/10.4018/978-1-59904-261-9

Kaklauskas, A.; Kanapeckiene, L. 2005. Knowledge management and "BRITA in PuBs" project, Technological and Economic Development of Economy 11(2): 78-86.

Kaklauskas, A.; Tupenaite, L.; Kanapeckiene, L.; Naimaviciene, J. 2013a. Knowledge-based model for standard housing renovation, Procedia Engineering 57: 497-503. https://doi.org/10.1016/j.proeng.2013.04.064

Kaklauskas, A.; Zavadskas, E. K.; Banaitis, A.; Banaitienė, N.; Kanapeckienė, L. 2012. Knowledge management in construction project management, Chapter 1, in V. M. Petrova (Ed.). Advances in engineering research. Vol. 3. New York: Nova Science Publishers, 1-90.

Kaklauskas, A.; Zavadskas, E. K.; Banaitis, A.; Banaitienè, N.; Kanapeckienė, L. 2013b. Knowledge management in construction project management, in N. Draskovic, T. Vukasinov (Eds.). Knowledge management: technology, applications and impact. New York: Nova Science Publishers, 91-188.

Kanapeckiene, L.; Kaklauskas, A.; Zavadskas, E. K.; Seniut, M. 2010. Integrated knowledge management model and system for construction projects, Engineering Applications of Artificial Intelligence 23(7): 1200-1215. https://doi.org/10.1016/j.engappai.2010.01.030

Kotter, J. P. 2008. Corporate culture and performance. New York: The Free Press.

Krejcie, R. V.; Morgan, D. W. 1970. Determining sample size for research activities, Educational and Psychological Measurement 30: 607-610.

Lawson, S. 2002. Knowledge management assessment instrument. Nova Southeastern University.

Lee, Y.-T. 2012. Global leadership in multicultural teams, in J. Canals (Ed.). Leadership development for a global world: The role of companies and business schools. The Palgrave Macmillan IESE Business Collection. https://doi.org/10.1057/9781137283320_9

Liao, S.-H.; Chang, W.-J.; Hu, D.-C.; Yueh, Y.-L. 2012. Relationships among organizational culture, knowledge acquisition, organizational learning, and organizational innovation in Taiwan's banking and insurance industries, The International Journal of Human Resource Management 23(1): 52-70. https://doi.org/10.1080/09585192.2011.599947

Liao, S.-H.; Wu, C.-c. 2010. System perspective of knowledge management, organizational learning, and organizational innovation, Expert Systems with Applications 37(2): 1096-1103. https://doi.org/10.1016/j.eswa.2009.06.109

Lin, H.-F. 2008. Empirically testing innovation characteristics and organizational learning capabilities in e-business implementation success, Internet Research 18(1): 60-78. https://doi.org/10.1108/10662240810849595

Lin, Y.-C. 2014. Construction 3D BIM-based knowledge management system: a case study, Journal of Civil Engineering and Management 20(2): 186-200. https://doi.org/10.3846/13923730.2013.801887

Lopes, C. M.; Scavarda, A.; Hofmeister, L. F.; Thomé, A. M. T.; Vaccaro, G. L. R. 2017. An analysis of the interplay between organizational sustainability, knowledge management, and open innovation, Journal of Cleaner Production 142: 476-488. https://doi.org/10.1016/j.jclepro.2016.10.083

Moustaghfir, K.; Schiuma, G. 2013. Knowledge, learning, and innovation: research and perspectives, Journal of Knowledge Management 17(4): 495-510. https://doi.org/10.1108/JKM-04-2013-0141

Moynihan, D. P.; Landuyt, N. 2009. How do public organizations learn? Bridging cultural and structural perspectives, Public Administration Review 69(6): 1097-1105.

https://doi.org/10.1111/j.1540-6210.2009.02067.x 
Mueller, J. 2012. The interactive relationship of corporate culture and knowledge management: a review, Review of Managerial Science 6(2): 183-201. https://doi.org/10.1007/s11846-010-0060-3

Obeidat, B. Y.; Tarhini, A.; Masa'deh, R.; Aqqad, N. O. 2017. The impact of intellectual capital on innovation via the mediating role of knowledge management: a structural equation modelling approach, International Journal of Knowledge Management Studies 8(3-4): 273-298. https://doi.org/10.1504/IJKMS.2017.087071

Pasher, E.; Ronen, T. 2011. The complete guide to knowledge management: A strategic plan to leverage your company's intellectual capital. New York: John Wiley \& Sons. https://doi.org/10.1002/9781118983782

Ringle, C. M.; Wende, S.; Will, A. 2005. Smart PLS Version 2.0 M3 (Version 2.0 M3). Hamburg: University of Hamburg.

Sanz-Valle, R.; Naranjo-Valencia, J. C.; Jiménez-Jiménez, D.; Perez-Caballero, L. 2011. Linking organizational learning with technical innovation and organizational culture, Journal of Knowledge Management 15(6): 997-1015. https://doi.org/10.1108/13673271111179334

Scarbrough, H. 2003. Knowledge management, HRM and the innovation process, International Journal of Manpower 24(5): 501-516. https://doi.org/10.1108/01437720310491053

Schein, E. H. 1996. Three cultures of management: the key to organizational learning, Sloan Management Review 38: 9-20.

Shenbagavalli, R. 2013. A strategy to manage the NPAs of public sector banks, International Journal of Management (IJM) 4(3): 1-7.

Smit, H. T.; Trigeorgis, L. 2012. Strategic investment: Real options and games. Princeton: Princeton University Press.

Taleghani, M.; Talebian, Z. 2013. Investigation of relationship between knowledge management and organizational culture in the National bank branches of Mazandaran province, Iran, Journal of Basic and Applied Scientific Research 3(3): 532-536.

Tohidi, H.; Jabbari, M. M. 2012. Main factors of organizational learning capabilities on product innovation performance, Procedia Technology 1: 544-547. https://doi.org/10.1016/j.protcy.2012.02.118

Tserng, H. P.; Lee, M.-H.; Hsieh, S.-H.; Liu, H.-L. 2016. The measurement factor of employee participation for Knowledge Management System in engineering consulting firms, Journal of Civil Engineering and Management 22(2): 157-167. https://doi.org/10.3846/13923730.2014.897963

Valencia, J. C. N.; Valle, R. S.; Jiménez, D. J. 2010. Organizational culture as determinant of product innovation, European Journal of Innovation Management 13(4): 466-480. https://doi.org/10.1108/14601061011086294

Vieira, D. 2013. Interorganizational learning in the Brazilian bioethanol industry, in Management Knowledge and Learning International Conference, 19-21 June 2013, Zadar, Croatia.

Wang, C. L.; Rafiq, M. 2009. Organizational diversity and shared vision: resolving the paradox of exploratory and exploitative learning, European Journal of Innovation Management 12(1): 86-101. https://doi.org/10.1108/14601060910928184

Zavadskas, E. K.; Kaklauskas, A.; Banaitis, A. 2010. Real estate's knowledge and device-based decision support system, International Journal of Strategic Property Management 14(3): 271-282.

https://doi.org/10.3846/ijspm.2010.20 